\title{
Compared education study: curriculum design for the development of competences (Tiradentes University - University of Deusto)
}

\author{
Letícia Soares de Vasconcelos Sampaio Suñé \\ and Roberto de Armas Urquiza*
}

doi: 10.18543/tjhe-3(2)-2016pp319-346

\begin{abstract}
A comparative education analysis between the competence-based curriculum deployed at the Deusto University and the Tiradentes University was done. The analysis has focused on the following aspects: Educational theories; Curriculum design; Psycho-pedagogical guidelines; Teaching, learning and evaluation methodologies; Planning of execution; Results/Impacts. The set of information of the Tiradentes University was coming from a pilot project on the implementation of competence-based education, which was conducted by the authors of this article during 2012 and 2013. The data and information from the Deusto University were collected from: reading of institutional and course documents (Administration and Company Direction); Monitoring of classes; and interviews. The results indicated broad convergence of methodologies used and the contribution of both to the improvement of the quality indicators of the courses in these institutions. Moreover, in certain respects each institution has effective contributions of teaching-learning methodologies that can be embraced by the mutual enrichment of competence-based education as practiced by the two universities.
\end{abstract}

Keywords: competences; curriculum design; integration; active learning; educational theories.

* Letícia Sampaio Suñé (letisune@gmail.com), PhD in Chemical Engineering, is a retired professor of the Chemical Engineering Department of the Federal University of Bahia (Brazil), with extensive experience in evaluation of courses and institutions in Brazil and Latin American countries. More details are provided at the end this article.

Roberto de Armas Urquiza (roberto@rect.uh.cu), PhD in Biological Sciences, is Emeritus Professor of the University of Havana (Cuba), with 50 years of experience in teaching, research and university management. More details are provided at the end this article. 


\section{Introduction: background and context}

The Latin America Tuning Project, during its two phases, 2004-2007 and 2011-2013, produced advances that have led to positive developments in the educational processes of the participating countries. ${ }^{1}$ The approach between teachers, researchers and representatives of organizations linked to higher education in different countries, allowed the effective construction of the new list of elements to consider in curricular designs, to give importance to social demands and achieve better learning effectiveness. All this was due to three main results of the Phase I of the Tuning Latin America, namely: general and specific competences; approaches to teaching, learning and evaluation; student workload. Similarly, the results obtained have allowed mutual understanding and identification of ideas and aspirations among the participants of the Tuning AL, which had the effect of causing concrete experiences of continuity and deepening of the project through cooperation between countries. So, there have been some successful initiatives, which have been structured and developed in order to achieve positive results for the institutions involved and are currently concrete examples of curricular innovations, which are disclosed in the countries involved. A typical example was the Competence-based Curriculum, developed and implemented at the Tiradentes University, Brazil, due of the cooperation established between this university and the University of La Habana, Cuba, through the representatives of these countries in National Tuning Centres. ${ }^{2}$

The preparation for the implementation of Curriculum Design to develop competences at the Tiradentes University ${ }^{3}$ (Unit for short) began in 2012. The project with students of Engineering courses (Environmental, Civil, Electrical, Control and Automation, Oil and Production) and of Business Area courses (Administration, Accounting and Technology courses in Human Resources) started in the first semester of 2013, at the campus of Unit, that is located in Aracaju, state of Sergipe, Brazil, and at the campus, located in the inner cities of the same state.

1 Argentina, Bolivia, Brazil, Chile, Colombia, Costa Rica, Cuba, Ecuador, El Salvador, Guatemala, Honduras, Mexico, Nicaragua, Panamá, Paraguay, Peru, Dominican Republic, Uruguay and Venezuela.

2 The authors of this article were the representatives of Brazil and Cuba.

3 The Tiradentes University is located in the state of Sergipe, Brazil. It's a recognized quality institution of Brazil, which develops teaching, research and extension. Currently offers 43 graduation university degrees, 5 Master and 4 Doctoral programs. It also offers various graduate and postgraduate e-learning courses. Develops scientific and applied research and is a university that has contributed to the development of the region where it operates. 


\section{I.1. Project characteristics}

The curriculum design for the development of competences covered the following phases: ${ }^{4}$

- Curriculum design

- Psycho-pedagogical references

- Planning and execution

- Monitoring and evaluation

\section{I.1.1. Curriculum design}

In a curriculum designed to develop competences the systematicity and the integration in the curriculum are important.

The first element, the systematicity, leads to the construction of the curriculum design with a systemic approach. Thus, the larger system - the professional profile - induces curriculum determination to vertical axes. In turn, these subsystems determine the other subsystems, namely: content matrix, curriculum horizontal axes, disciplines, learning programs and lesson plans. All subsystems are designed with a focus on competences profile to be developed by the student. For example, each horizontal axis is associated with a particular competences profile, so that the student, after completing a specific academic period (semester or year), has developed the associated competences set to that period. The general competences profile was built from the competences proposed in the Latin America Tuning Project ${ }^{5}$ and completed based on questionnaires sent to different work scenarios with the aim of identifying the profession tasks, action fields and acting spheres of graduates.

The second element underlying the curriculum design is the integration at all levels: intra-disciplinary and interdisciplinary. The intra-disciplinary integration focuses on the logical and coherent development of the content of each discipline with a view to the perception of the whole. In turn, interdisciplinary integration is produced in the following ways:

- The contact points between disciplines.

${ }^{4}$ Letícia S. Suñé, Paulo J.L Araújo, and Roberto de Armas, Desenho de currículo para desenvolver competências: uma proposta metodológica (Aracaju: Editora Unit., 2015).

${ }_{5}^{5}$ Pablo Beneitone, César Esquetini, Júlia González, Maida Marty, Gabriela Siufi, and Robert Wagenaareds, Reflexões e perspectivas do ensino superior na América Latina (Bilbao: Publications of the Deusto University, 2007). 
- The development of full horizontal integration between the disciplines of a same academic period, through an integrative discipline that aims to ensure the development of the period competences profile.

- The cross training which works across the curriculum competences, in context in different subjects throughout the course.

- The vertical integration that occurs between the subjects of the vertical axis, to enable the learning progression of a given subject area and hence the competences profile associated with these axes.

Silva $^{6}$ stated that there is interdisciplinary integration when there are actions that contribute to the integration of various fields of knowledge, building the scientific knowledge in a systemic way, so that the interactions between systems avoid fragmentation. Only integration can ensure interdisciplinarity, and therefore the development of complex thinking in students, which is essential for the educational pathway of professionals who are able to give solutions to the problems that life presents, in professional, personal and community levels. Tobón ${ }^{7}$ said that complex thinking complements the systemic approach enabling a knowledge construction method that takes into account the links between the parties, building relationships, chaos, change and uncertainty.

\section{I.1.2. Psycho-pedagogical references}

In teaching and learning processes it is essential to know not only how students learn but also the teachers should use different methodologies to achieve an effective learning. In this sense, Galperin ${ }^{8}$ postulated the theory of learning by stages. This theory states that the student interacts with the objects of study through actions that evolve from the external phase, called material or materialized, and reaches the internal phase, called mental. These steps, however, signal the way of construction and internalization of knowledge, namely:

- Motivation 2012).

${ }^{6}$ Antonio Carlos Ribeiro Silva, Educação por competências (Jundiaí: Paco Editorial,

Sergio T Tobón, Formación basada en competencias (Bogotá: Ecoe Ediciones, 2005).

${ }^{8}$ Galperin cited by García Mendoza, Héctor J., Ortiz Colón, Ana M., Martínez Moreno, Juan, and Tintorer Delgado, Oscar, "La Teoría de la Actividad de Formación por Etapas de las Acciones Mentales en la Resolución de Problemas,” Inter Science Place 1, no. 9 (2009): 1-25. 
- Guiding Basis of Action

- Material step

- Verbal step

- Mental step

Learning begins when the student in a concrete teaching situation makes the first contact with the proposed action to promote his/her interaction with the object of study in its material or materialized form; then advances to the step in which the student already dominates the structure of action and has acquired the knowledge needed to develop the action, so that he/she can express in the oral or written language plan with the teacher, other students or himself/herself; finally learning reaches the stage where the action is internalized and incorporated into the student's mental plane. When the student arrives at this point acquires independence by developing the ability to generalize and apply knowledge to new situations in different contexts.

In order to take place effectively, learning must be preceded by two other steps: motivation, addressed to stimulate interest and lead to a positive attitude of students toward learning, and Guiding Basis of the Action which consists of a set of operations that meets certain order and rules that must be followed by the student in order to facilitate the implementation of the action. According to Díaz Pupo, ${ }^{9}$ the guiding bases create internal mechanisms necessary for the development of strategic learning skills. The absence of a Guiding Basis of the Action leads the student to develop the action through trial and error, especially in his/her first contact with an action proposal to work a particular object of study. The Guiding Basis of the Action was one of the valuable elements contributed to competences curriculum methodology, which allowed students with knowledge gaps to organize and structure the thinking in the development of interaction activities with the objects of study, making them advancing their learning processes.

As to the teaching methods used in the curriculum to develop competences, any methodological strategy is valid, when it enables the active participation of students in the learning process and takes into account the following aspects:

- The type of content that should be worked

- Learning objectives of the disciplines and disciplinary axes to be achieved and the competences to be developed

9 Arledys Díaz Pupo, "Propuesta de bases orientadoras de la acción para estimular las habilidades conformadoras del desarrollo personal desde la asignatura "Psicología de la personalidad' en condiciones de Colegios Universitarios Municipales," Pensando Psicología 6, no. 10 (2010): 75-96. 
- The characteristics of students

- The resources available.

Moreover, it is important to remember that education to develop competences should focus on learning to action and resume the true meaning of knowledge, from its functionality, as commented by Zabala and Arnau. ${ }^{10}$

Experience has shown ${ }^{11}$ that the following active methods are very effective in developing of competences:

- Project Oriented Learning - POL $;{ }^{12},{ }^{13}$

- Case Studies as teaching method

These were therefore the psycho-pedagogical and methodological assumptions that supported the planning and implementation of the teaching process and learning in a curriculum to develop competences, which are summarized in the mental map of Figure 1.

\section{I.1.3. Planning and execution}

The joint planning among teachers before the beginning of each academic year must be a necessary step in the competence-based curriculum. It is what allows true integration and interdisciplinarity at all levels. One of the hardest aspects of the implementation of the curriculum was to change the mind-set of teachers to break paradigms and move from an individual pedagogical practice to a new one, built on team. This aspect requires constant planning workshops of teaching activities, every three months, including:

- Programs of teaching and learning

- Lesson plans

- Activities inside and outside the classroom

- Interdisciplinary activities

- Projects of integrating axis

- Evaluation Memorials.

10 Antoni Zabala and Laia Arnau, Métodos para la enseñanza de las competencias (Barcelona: Editorial GRAÓ, 2014).

${ }^{11}$ Letícia S. Suñé, Paulo J.L.Araújo, and Roberto de Armas, Desenho de currículo para desenvolver competências: uma proposta metodológica (Aracaju: Editora Unit, 2015).

12 Antoni Zabala and Laia Arnau, Métodos para la enseñanza de las competencias. Barcelona: Editorial Graó, 2014.

${ }_{13}$ William N Bender, Aprendizagem baseada em Projetos: educação diferenciada para o século XXI (Porto Alegre: Editora Penso, 2014). 


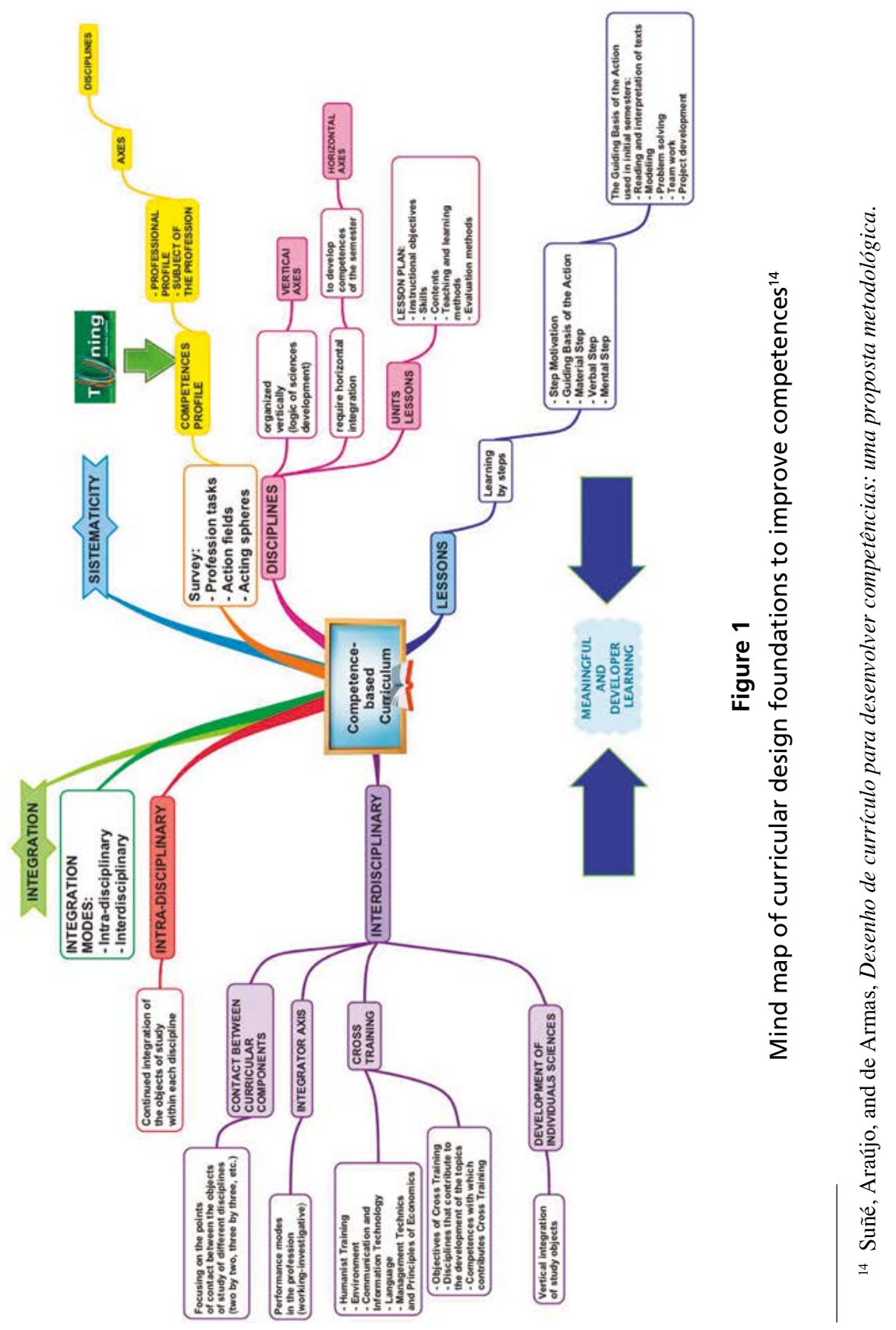




\section{I.1.4. Monitoring and evaluation}

Academic leaders and managers of the project ${ }^{15}$ monitored the entire implementation process. They oversaw the planning documents and the practice in the classroom, in order to observe how teachers were applying the plans at the end of the teaching and learning process.

On the other hand, the monitoring of project development utilized quality indicators provided by the following ratings, regularly applied at the end of each academic year:

- Student self-evaluation for the development of general competences: analysis and interpretation of texts, problem solving, teamwork, modelling and development projects.

- Teacher evaluation by students

- Teaching self-evaluation

- Calculation of qualification and abandonment levels based on the academic data of the students stored in the management system.

\section{Research structuring}

Considering that curricula are complex and dynamic structures, this study did not aim to cover all curricular variables. The research focused on the development of competences by the students, so that sought to identify the following aspects:

- Educative theories

- Curriculum design

- Psycho-pedagogical guidelines

- Teaching methodologies, learning and evaluation

- Execution planning

- Results/Impacts

The issues that led to this study were motivated by a comparative approach in order to identify which aspects were decisive for the success of the methodology used in both universities. The purpose was to highlight best practices and to contribute to the enrichment of these methodologies. Therefore, the questions that guided the research were: "how" each university

15 Project of Curriculum Design to develop competences at the Tiradentes University. 
applies its methodology to develop students' competences, "why" these methodologies have led to improved learning and "which" are the key aspects of each one of them. For this reason, in both cases, aspects of the curriculum that could provide answers to these questions have been studied and analysed. The comparative analysis is described at the Section III.

\section{II.1. Planning activities}

This research is a qualitative analysis that is based on explicit comparisons between the curriculum of the Tiradentes University - Unit, located in Aracaju, Brazil and the University of Deusto - UD located in Bilbao, Spain, using the case study approach. Thus, provided that an explicit comparison emphasizes contrasts and reveals the similarities. ${ }^{16}$

The structure of compared education study is based on the following elements:

\section{Table 1}

Planning of research activities in the DITA short-term visit

\begin{tabular}{|c|c|c|}
\hline Aspects & Information sources & Research tools \\
\hline $\begin{array}{l}\text { Conceptual } \\
\text { framework of the } \\
\text { institution and the } \\
\text { course (Business } \\
\text { Management } \\
\text { Administration and } \\
\text { Company Direction) }\end{array}$ & $\begin{array}{l}\text { Institutional documents: } \\
\text { - Pedagogical framework } \\
\text { of Deusto University; } \\
\text { - Teaching and learning } \\
\text { model of the Deusto } \\
\text { University; } \\
\text { - Educational Project. }\end{array}$ & $\begin{array}{l}\text { - Reading and analysis } \\
\text { of documents. }\end{array}$ \\
\hline $\begin{array}{l}\text { Academic semester } \\
\text { planning }\end{array}$ & $\begin{array}{l}\text { - Study program of the } \\
\text { discipline (Student } \\
\text { Learning Guide); } \\
\text { - Interviews to collect } \\
\text { information on the } \\
\text { planning of teaching } \\
\text { activities (to confirm that } \\
\text { occurs in teacher groups } \\
\text { or individually); } \\
\text { - Materials to support } \\
\text { teaching and learning. }\end{array}$ & $\begin{array}{l}\text { - Reading and analysis } \\
\text { of documents. } \\
\text { — Interview with the } \\
\text { managers of the } \\
\text { course of Business } \\
\text { Management } \\
\text { Administration and } \\
\text { Company Direction. }\end{array}$ \\
\hline
\end{tabular}

16 Mark Bray, Bob Adamson, and Mark Mason, Educación comparada: enfoques y métodos (Buenos Aires: Ediciones Granica S.A, 2010). 


\begin{tabular}{|c|c|c|}
\hline Aspects & Information sources & Research tools \\
\hline $\begin{array}{l}\text { Execution of the } \\
\text { process of teaching } \\
\text { and learning }\end{array}$ & $\begin{array}{l}\text { - Curricular integration; } \\
\text { — Investigative-professional } \\
\text { axis; } \\
\text { - Roles of teachers and } \\
\text { students; } \\
\text { - Use of active methods of } \\
\text { teaching; } \\
\text { - The commitment and } \\
\text { motivation of students } \\
\text { with activities; } \\
\text { - The interaction level in } \\
\text { class activities (use of } \\
\text { group work, development } \\
\text { of communication skills } \\
\text { and reasoning of the } \\
\text { students); } \\
\text { - Forms of assessment: } \\
\text { self-assessment, } \\
\text { co- assessment and } \\
\text { assessment by the } \\
\text { teacher. }\end{array}$ & $\begin{array}{l}\text { - Observation of } \\
\text { lessons; } \\
\text { — Interviews with those } \\
\text { responsible for the } \\
\text { course of Business } \\
\text { Management } \\
\text { Administration and } \\
\text { Company Direction. } \\
\text { - Interviews with } \\
\text { teachers and } \\
\text { students. } \\
\text { - Access to methods } \\
\text { and evaluation tools. }\end{array}$ \\
\hline Results/Impacts & $\begin{array}{l}\text { - Capacities development } \\
\text { for students. } \\
\text { - The changing in attitudes } \\
\text { of students; } \\
\text { - The transformation in } \\
\text { thinking and acting of } \\
\text { teachers. }\end{array}$ & $\begin{array}{l}\text { - Interviews with } \\
\text { teachers and } \\
\text { students. } \\
\text { — Quality indicators of } \\
\text { the courses (evasion } \\
\text { and approval). }\end{array}$ \\
\hline
\end{tabular}

\section{II.2. Information sources}

During the period of investigation full access to the course of Business Management Administration and Company Direction of Deusto University was provided to the researcher, so it was possible to work with the following sources of information:

Course and Institutional documents:

- Pedagogical framework of Deusto University

- Strategic Plan of Deusto University

- Teaching and learning model

- Student learning guide 
- Educational Project of Business Management Administration and Company Direction Course

- Competences of Business Management Administration and Company Direction Course

- Some disciplines specifics materials (evaluation criteria/feed back to students)

Monitoring of classes of Business Management Administration and Company Direction Course:

- Microeconomics (period 1)

- Accounting (period 1)

- Budgetary Forecast and Management Control (period 2)

- Direction of People (period 3)

Interviews:

- Teachers of Business Management Administration and Company Direction Course.

- Students of Business Management Administration and Company Direction Course.

- Responsible for the course of Business Management Administration and Company Direction.

\section{The comparative analysis of the collected information}

\section{III.1. Educative theories}

The first look when curricular concepts are compared is the educational theory that supports them. According to Bray, Adamson and Mason,

Different curriculum concepts are nourished by ideologies supported in the formative looks and beliefs about the desired roles for schooling in society, the nature of knowledge and learning and the roles of students and teachers.

There is evidence that the curriculum conceptions of both institutions, DeustoUniversity and Tiradentes University, are nourished both of progressivism as of cognitive pluralism. Both universities have a student-centered design and are associated with constructivist learning models that drive students to explore and develop independently and to be active builders in their own learning (progressivism). On the other hand, both curricular concepts (Deusto University 
and Tiradentes University) promote the development of multiple intelligences and a diversity of attitudes and competences and students are seen as apprentices in various skills that make them able to incorporate the context of the everchanging demands (cognitive pluralism).

A comparative analysis based on the approaches adopted in the present investigation is presented below:

\section{III.2. Curriculum design}

The curriculum design is an inductor element of competences development. Its structure should be based on assumptions that give purpose and meaning to structuring the set of disciplines that make up the curriculum of the course. Curricular axes, as well as the sequence and simultaneity of the disciplines in the composition of these axes should reflect an organizational structure that, once completed by the students, contributes to the final proposed professional profile.

\section{Deusto University}

As a result of Deusto University to be one of the principal participants of the Tuning Project, its courses have gone through a curriculum innovation process in order to implement competence-based education.

In this process, the basis for the preparation of curriculum design was the professional profile established through:

- Opinion polls and interviews with teachers, students, alumni and employers

- Market research conducted by one independent company

- Analysis of similar studies of curriculum innovation

- Analysis of the results of the Tuning Project

- Benchmarking with other universities

Due to the proximity of the University with the professional sector, the alumni helped to establish the basic characteristics of competences. The competences profile was contrasted with students who were at the end of their university degree.

Therefore, the basis of curriculum design was the professional profile expressed in competences, from which the disciplines have been established. 
The curriculum of Business Management Administration and Company Direction Course (UD) establishes interdisciplinarity, only in the disciplines of Graduate Final Project and Practices in Business. The integration between disciplines is not in an effective practice however some disciplines, for its interdisciplinary characteristics, allow some level of integration, such as finance disciplines, which has a cross-cutting nature, and therefore integrative. This is an important aspect because without the integration it is not possible to develop competences.

\section{Tiradentes University}

The elements that support the curriculum design centered on competences development adopted by the Tiradentes University are systematicy and integration. Through systematicy, the disciplines are developed as subsystems of a larger system, the professional profile, to form an articulated structure of disciplines, the curriculum, with a purpose and a meaning. This arrangement is also based on the logic sequence of disciplines in each vertical axis of the particular sciences, as well as simultaneity of these disciplines in each horizontal axis in order to facilitate integration and the consequent interdisciplinarity. In the methodology of the Tiradentes University, integration is one of the aspects considered essential because the competences are formed from the mobilization and integration of diverse knowledge (conceptual, procedural and attitudinal). The integration results in the development of complex thinking. ${ }^{17}$ In order to give appropriate answers to the problems that life presents, students need to develop complex thinking, since the actual situations are not mono-disciplinary or linear, but multidisciplinary, cross-cutting, multi-dimensional, and therefore complex.

\section{III.3. Psycho-pedagogical guidelines}

The psycho-pedagogical guidelines adopted use a psycho-pedagogical model that facilitates the way of construction of knowledge and development of competences by students.

In both institutions, Tiradentes University and Deusto University, pedagogical guidelines based on constructivist psychology of cognitive

${ }_{17}$ Edgard Morin, Os sete saberes necessários à educação do futuro (São Paulo: Cortez; Brasília, DF: UNESCO, 2011). 
character are adopted, namely socio-interactionist constructivism, because students learn through interactive activities with the objects of study and other social subjects (colleagues, teacher, community, etc.).

In terms of learning model, the two institutions adopt models that follow different paths, but with many similarities between them. Both models rely on procedures to give meaning to the study objects and appropriation of knowledge through internalization of interaction actions with the study objects that evolve to the mental stage, so that the student acquires the ability to apply the structures of thought to new situations other than those in which learning actions have been developed.

\section{Deusto University}

The Deusto University uses a learning model based on Kolb's experience ${ }^{18}$ and Ignatian Pedagogy. ${ }^{19}$ In this model, learning is introduced cyclically into five main steps:

- Experiential Context

- Reflective Observation

- Conceptualization

- Active Experimentation

- Evaluation

\section{Tiradentes University}

The University Tiradentes works with the model of development in steps of Galperin (see I.1.2), which describes the steps that students perform from the external phase (material) to the mental phase, through the interaction of actions with objects of study

The Guiding Basis of the Action contributes significantly to student learning, and prevents that method of trial and error can be used by students who develop, for the first time, an action on a particular object of study.

${ }_{18}$ Alice Y. Kolb and David A. Kolb, The Kolb Learning Style Inventory - Version 3.1 2005 Technical Specifications (Boston and London: HayGroup, 2015). http:// learningfromexperience.com/media/2010/08/tech_spec_lsi.pdf.

19 The Ignatian Pedagogy is a teaching and learning model that incorporates principles of Jesuit Education, http://jesuitinstitute.org/Resources/Ignatian\%20Pedagogy\%20(JI\%20 Edition\%202013).pdf. 
Burón ${ }^{20}$ highlights the need for students to establish metacognitive strategies that help them to structure their learning process. It is observed that the Guiding Basis of the Action works with this feature, and therefore leads to better learning outcomes.

\section{Comparative analysis}

The analysis of cognitive operations provided in each stage of the design allows to identify a broad agreement between the two learning models.

The experiential context has common features with the motivation step. For both models, this is the time to link up with other contexts and encourage a positive attitude of the student, as well as the interest and the willingness with respect to the topic discussed. Both steps use as a means to promote motivation, documents, sounds, images, graphics, etc. The pedagogical mark of the Deusto University ${ }^{21}$ explains the following:

In summary, this first step is to place the student at the topic or issue to develop. Therefore, at this stage what matters is to motivate the student through his experience and background, so that he gets a first global approach to the subject.

In the reflective observation, memory, understanding, imagination and feelings are used to grasp the meaning and the essential value of what is being studied. The purpose of reflective observation is that people learn to ask questions and have a questioning attitude, to achieve a significant learning. Taking this into account, some similarity of the reflective observation with the material step (in which there is a perception of the structure of action to be developed) and the verbal stage (where the student verbally shares his reflection on the action, with himself or other social subjects) can be found.

The conceptualization of the learning model of the Deusto University is a step in which the student acquires the knowledge, scientific terminology, facts and figures, methods and strategies that form the scientific knowledge for each subject. However, this is not a memorization step, but the learning based on the use and application of cognitive skills (understanding, analytical and synthetic thought, critical judgment and divergent thinking) that allows

20 Javier Burón, Enseñar a aprender: introducción a la metacognición (Bilbao: Ediciones Mensajero, 2012). 2001).

${ }^{21}$ Universidad de Deusto, Marco pedagógico (Bilbao: Artes Gráficas Rontegui, S.A.L., 
an integrated learning (where the concepts and theories are integrated on its own intellectual framework) and significant (incorporating relevant knowledge for personal development linked to attitudes, values and competences). In the model of the Tiradentes University the conceptualization is associated with various operations related to the development of actions in which the student interacts with the objects of study. In developing the action (or actions) by which a task or activity is performed, the student has to perform a series of operations, including the conceptualization in various degrees. The Guiding Basis of the Action indicates the critical path that the student must follow to build the learning, that is the operations that he/she must perform to do a task, as well as the sequence in which these operations are to be performed, ${ }^{22}$ in order to develop his/her conceptualization abilities at different times and with different level of depth. In material step students take a more superficial initial conceptualization, which is intensified in the verbal step, and reaches the highest level in mental step where knowledge is linked to mental structures development.

An important aspect to highlight is that the model of the Tiradentes University prioritizes the contextualization of concepts and knowledge mobilized in real or simulated activities of labour scenarios. Thus, the student acquires the ability to generalize, that is, to apply the knowledge in the development of actions related to new contexts.

The model of the Deusto University defines the active experimentation as the theoretical and practical linking stage, which includes any activity that encourages the development of skills and abilities of students in the application of concepts, theories or models in order to solve problems and/or develop projects and/or implement models and strategies. In model of Tiradentes University, the experimentation has its guidelines generated by the Guiding Basis of the Action and occurs in three steps, material, verbal and mental, where the interaction of the student with the object of study is realized through action. Therefore, in the model of Tiradentes University learning is always produced in association with the resolution of an activity or task linked with the scenario of professional career, so the trial is inherent to the learning steps.

The evaluation is the last phase of the learning model of the Deusto University; it is held at three levels: personal, formative and summative. In the model of the Tiradentes University evaluation does not appear explicitly as a learning step, even when the action development strategy is incorporated

${ }^{22}$ Letícia S. Suñé, Paulo J.L. Araújo, and Roberto de Armas, Desenho de currículo para desenvolver competências: uma proposta metodológica (Aracaju: Editora Unit, 2015). 
in the mental plane, the students acquires the ability to self-evaluation and evaluate other people, an aspect that will contribute to their continuous improvement, as well as their classmates. The summative evaluation is not incorporated in the Tiradentes Universty model because it is not part of learning, but rather a result of learning.

Despite the different names and different psycho-pedagogical approaches, the important thing is that both models of learning, Tiradentes University and Deusto University converge on the induction capacity of educational processes leading to the construction of knowledge and the effective competences development.

\section{III.4. Teaching, learning and evaluation methods}

The use of active methods is necessary in innovative curricula that choose a student-centred teaching-learning process.

The active learning methodologies facilitate meaningful learning that is closely related to the development of competences. The only use of active learning methods does not ensure the development of specific skills, but activates student learning facilitating the achievement of competences. It is important to remember that competences development requires the integration of knowledge.

\section{Deusto University}

Active learning methods are widely used in Deusto University. Based on the documents of Administration and Direction of Company course and the observation of teaching, it was found that the following methodological strategies are used:

- Presentation of content by the teacher

- Reflection and discussion

- Documentation Analysis

- Preparation of work

- Analysis and discussion of case studies

- Application exercises in very different situations of the company

- Oral exhibition of work

- Role-playing

- Discussion

- Written reports

- Visits to companies 
- Generation of direction skills

- Business Games

Deusto University teachers plan the teaching activities through documents that are a support to the processes of teaching, learning and evaluation, among which stand out:

- Student Learning Guide

- Feedback to Students

These documents help structuring and planning of the teaching process, because they propose appropriate teaching methods to develop competences and explain the contents, as well as the evaluation plan which sets out, for each competence, indicators, criteria (reflecting the observed performance), the evaluation technique, and the weighting factor. A student-learning guide consists of three tables:

- Table I: Teaching Strategies/Learning of Competences (strategies are chosen taking into account the competences to be developed and the contents to be used as a means to develop these competences).

- Table II: Student Work Plan (where the competences to be developed are correlated with: the content, the activities to be carried out, the type of activity, the material used and the time in class and outside of class).

- Table III: The Competences Evaluation System (correlates each competence with the corresponding evaluation indicators, performance criteria, evaluation techniques and weighting factors).

All teachers prepare this document, some more simply and others with great detail and more complete. This is a great advantage offered by Deusto University methodology because it supports teachers to develop planning for their disciplines with a focus on competences that will be developed by the students.

Another document used is the feedback for students, where the students' observed performance are compared to the desired performance, accompanied by their evaluation. This evaluative record offers a personalized monitoring of students, in that it describes the performance of each student, compared to the established criteria. This consists of excellent student feedback tool that enables continuous improvement of their learning process.

On the modalities of evaluation, the Deusto University uses not only hetero-evaluation, but also uses the self-evaluation and co-evaluation. In relation to the moments when the evaluation is performed, the Deusto University works primarily with the formative dimensions (along the course) and summative ones (end of course). 


\section{Tiradentes University}

Tiradentes University encourages the adoption of active methodologies by teachers, so that the training is offered continuously to teachers in workshops that take place every three months. The methods used are:

- Dialogic and participatory presentation

- Project Oriented Learning - POL

- Case Studies

- Peer Instruction

- Gamification

- Problem Based Learning - PBL

- TBL - Team Based Learning

- Role-playing

- Inverted Class

Within these methodologies students develop various activities such as:

- Reading and analysis of documents

- Bibliographic search

- Writing report

- Problems solution

- Oral presentation of works

- Teamwork

- Presentation of seminars

It is also considered important to refer to the strategy developed by the Unit for teamwork through a Guiding Basis of the Action developed for this purpose. This work is always problematic because of the tendency of active participation of some students, while others do not cooperate effectively with the development of activities. In order to foster active participation in all activities carried out in teams, the Unit works with five member groups, each of which plays a specific function, as follows: ${ }^{23}$

- LEADER - Determines the systematic flow of events, applies the evaluation models of planning and other needs, directs and controls the flow of resources.

- VICE LEADER - Replaces the Leader in case of absence. Determines the goals and objectives, identifies performance criteria, the limits and

${ }^{23}$ Letícia S. Suñé, Paulo J.L. Araújo, and Roberto de Armas, Desenho de currículo para desenvolver competências: uma proposta metodológica (Aracaju: Editora Unit, 2015). 
pressures, determines the sequence of activities and strategies consistent with the goals and objectives.

- PRESENTER - Transcribe and displays the results in a coherent and understandable way for the team.

- RESEARCHER - Develops models for data collection, recommends sources of research or people to consult, collects information about the data and how the work is being done, identifies the necessary information, the sources of necessary basic knowledge, brings to the group all the material need (knowledge base, data and information).

- DESIGNER/DEVELOPER - Organizes graphic expressions of the work that is being developed, as well as the programming language in itself.

Usually the job rotation is performed, each new group activity, to ensure that students assume all roles, an aspect which is positively reflected in its training.

Regarding the planning instruments of educational activities, the Tiradentes University works with the following documents:

- Plan for Teaching and Learning (discipline planning)

- Integrated Work Plan (planning of learning times)

- Evaluation Memorial

In the Plan of Teaching and Learning ${ }^{24}$ teachers specify learning outcomes to be achieved and the corresponding skills whose development should be promoted by the discipline, content and teaching strategies to be used, activities that develop inside and outside of the classroom and the estimated student time spending with the completion of these activities. On Memorial Evaluation criteria and the tools that will be used in each evaluation are established.

The Tiradentes University uses the following types of evaluation: heteroevaluation, self-evaluation and co-evaluation. Regarding time when the evaluation is performed, this university proposes formative evaluation during the development of the semester, and the final evaluation (summative) at the end of the semester. Some teachers do in their disciplines diagnostic evaluation voluntarily. The implementation of the curriculum for the development of competences in Tiradentes University caused a greater participation of procedural evaluation, formative character, in the evaluative judgment on the qualifying conditions for students.

${ }^{24}$ Unit internal planning document. 
Comparative analysis

With regards to teaching, learning and evaluation methods, we conclude that both the Deusto University and the Tiradentes University develop their educational activities with a focus on competences to be developed by students. The guidelines used at both institutions fulfil their role of making teachers working on content as a means and not as an end. Both in Deusto University as the Tiradentes University teachers work with active and varied teaching methodologies that facilitate the learning process of students. Namay Zevallos ${ }^{25}$ states that effective teaching methods include the approach of problem situations that describe practical situations, an aspect that is contemplated by the two Universities. Evaluation is also carried out with a focus on developed competences that are valued by the use of criteria that describe the learning outcomes expected of students at different levels of reach. In addition, in the two institutions the evaluation is made by the teacher (hetero-evaluation), but also, by the students themselves (self-evaluation) and as well as evaluate their colleagues (coevaluation).

In comparative terms, the document structure of the teaching process, learning and assessment used by Deusto University allows better organization of activities in class, and induce teachers to follow to the model adopted in the institution to develop competences. Moreover, these documents consist of tools to aid the student to reflect in relation to their own learning process. In this sense, it is considered that the documents supporting the workroom developed by Deusto University provide a significant contribution to the development of skills by students.

\section{III.5. Planning of execution}

Planning for the implementation of the academic period is of strategic importance in competence-based education, because it allows to implement teaching-learning process in accordance with the guidelines established in the institutional pedagogical framework.

${ }^{25}$ Wilder Namay Zevallos, "La teoría de la formación por etapas de las acciones mentales de Galperin: un esbozo teórico y casos prácticos,” Scridb. https://pt.scribd.com/doc/115043666/ La-teoria-de-la-formacion-por-etapas-de-las-acciones-mentales-de-P-Y-Galperin-Esbozoteorico-y-casos-practicos. 


\section{Deusto University}

At the Deusto University planning is developed by each teacher. Only teachers of the same discipline plan together. In the planning process, each teacher prepares the Student Activity Guide, a document mentioned earlier (III.3. Teaching Methodologies, Learning and Evaluation).

The didactic planning involves general and specific competences to be developed in each subject (each subject is linked to a department). The Director of the Department approves and oversees each teaching activity guide, and supervises the implementation of the subject in order to ensure the development of competences.

The teachers training at Deusto University takes place systematically and, according to teachers, it has allowed the use of teaching strategies in the classroom, with mastery and efficiency, as it has been seen in the classes visited during the development of this research.

\section{Tiradentes University}

In Tiradentes University, planning is carried out jointly with the participation of teachers from all disciplines of an academic semester, to ensure the integration, which is one of the pillars of the adopted curriculum design. Through joint planning, interdisciplinary activities and workinginvestigative axis are structured.

The systematic training of teachers takes place in workshops in which teachers plan and discuss their teaching and learning plans, as well as receive training adapted to the educational guidelines and active methodologies of curriculum to develop competences. Before the start of each school year, after the teachers' vacation, these are dedicated to joint planning in workshops, always accompanied by the course coordinator. At such times it is done all the planning of the academic semester, which includes the preparation of interdisciplinary activities and working-investigative axes that develop, usually, through projects.

Comparative analysis

Both institutions use planning as a key element of putting into practice of curriculum design. However, the Tiradentes University performs planning jointly, through workshops in which teachers work to integrate 
the disciplines of each semester, in order to ensure the practice of interdisciplinary leading to complex thinking. This is the greatest contribution of the Tiradentes University methodology to the curriculum for competences.

Both institutions provide tools for teachers to act in order to stimulate the development of the competences by students, an aspect that is consolidated through the continuous training of teachers. Despite this, there are teachers who work well active methodologies and others who do not. Both Deusto University as the Tiradentes University understand that this is a continuous improvement process where teachers use more effectively the active methodologies during the new academic year.

\section{III.6. Results/ Impacts}

Results/impacts of the use of methodologies in the two universities consist of fundamental aspect of the studies focused on teaching and learning processes. The greater importance of promoting improvements in teaching and learning processes has favourable impact on personal and professional development of students. This analysis should be carried out by means of quality indicators of higher education.

\section{Deusto University}

At the Deusto University the monitoring of students' results is done by collecting data in a computer system. The curriculum innovation based on the Bologna process started from July 2009, so that the first group of students of the curriculum for competences entered the University in 2009/2010.

It was not possible to obtain comparative results of academic performance indicators of students before and after curriculum changes, but the current indicators point out an improvement above 94\% and the approval from employers concerning the profile of graduates by is higher than $90 \%$ (Deusto Alumni).

\section{Tiradentes University}

The Tiradentes University monitors the results of the competence-based education through the following ratings: 
- The student survey regarding the acquisition of the following competences: motivation; interpretation of texts; teamwork; problems solution

- Teaching evaluation by students regarding the use of curriculum methodology for the development of competences

- Teaching self-evaluation regarding the use of curriculum methodology for the development of competences

- Calculation of quality indicators of higher education (abandonment, qualifications, etc.), based on statistics

Here are some results of the Business Area courses.

Table 2

First year students - 2013-1

(the development of basic competences)

\begin{tabular}{|l|l|c|}
\hline \multicolumn{2}{|c|}{ Number of Students Consulted - 255 } \\
\hline Motivation & Increased & $72 \%$ \\
\cline { 2 - 3 } & Has not changed & $26 \%$ \\
\cline { 2 - 3 } & Decreased & $2 \%$ \\
\hline \multirow{5}{*}{ Interpretation of texts } & Increased & $66 \%$ \\
\cline { 2 - 3 } & Has not changed & $34 \%$ \\
\cline { 2 - 3 } & Decreased & $0 \%$ \\
\hline \multirow{5}{*}{ Problem solving } & Increased & $75 \%$ \\
\cline { 2 - 3 } & Has not changed & $25 \%$ \\
\cline { 2 - 3 } & Decreased & $70 \%$ \\
\hline & Increased & $29 \%$ \\
\cline { 2 - 3 } & Has not changed & $1 \%$ \\
\cline { 2 - 3 } & Decreased & \\
\hline
\end{tabular}

An increase in qualification (percentage of students who have passed in all subjects of the semester) levels was observed when comparing the periods before and after the implementation of the curriculum for competences, as shown in the following Tables 3 and 4. 


\section{Table 3}

Comparative analysis of average approval rates in the Business Area courses (students who attend the first semester)

\begin{tabular}{|c|c|}
\hline compared Semesters & Evolution of Qualifications \\
\hline $2012-1$ vs $2013-1$ & $63 \%$ P $67 \%$ \\
\hline $2012-2$ vs $2013-2$ & $59 \%$ P $67 \%$ \\
\hline
\end{tabular}

Table 4

Comparative analysis of average approval rates in the Business Area courses (students entering in 2013-1 and who were in the second semester of the course)

\begin{tabular}{|c|c|}
\hline Compared Semesters & Evolution of Qualifications \\
\hline $2012-2$ vs $2013-2$ & $73 \%$ P $85 \%$ \\
\hline
\end{tabular}

Table 4 indicates a significant increase in approval ratings (12\%), a situation that reflects a better student learning, which can be understood in the following aspects:

- Overcoming the initial difficulties of adapting to new University study rhythms

- Increased basic abilities of students because of the intensive use of Guiding Basis of the Action in the first semester of Business Area courses

It is important to bear in mind that the competence-based education began to be implemented at the Tiradentes University in 2013-1.

\section{Comparative analysis}

With respect to results, the comparative analysis between the Deusto University and the Tiradentes University is made more difficult by the many variables that affect in both contexts. So, the important thing is to analyse the benefits of education to develop competences in these institutions.

At Deusto University, although it was not possible to obtain quantitative indicators before the adoption of competence-based education, current statistics indicate high levels of performance of students. Another significant 
aspect is that teachers claim that students are more engaged and motivated with the course, after the implementation of the curriculum for competences.

In Tiradentes University, qualitative and quantitative data make clear the student satisfaction with the perception they have of the increase in basic skills, as well as improved performance reflected the evolution of average approval rates.

\section{Final conclusions}

The comparative analysis of the curricular structures indicates that there are several points of convergence because the paths that in principle may look different in reality often express the same idea. In some aspects, methodologies separately have a higher evolution, generating contributions that can be used to the mutual enrichment of teaching and learning processes of the two institutions, the Deusto University and the Tiradentes University.

Some of these contributions are reported below as best practices of competence-based curricula design and implementation that can be transferred in different contexts.

The documents used by the Deusto University in the planning process of teaching and learning leads teachers to keep the focus on the best suited conditions to the development of competences by the students seem very relevant.

The documents used by the Deusto University to support the evaluation of learning that focus on competences developed by the students, with the proposition of indicators and benchmarks, as well as tools for feedback provided by teachers to students appear as very useful. The model contributes to the quality of learning evaluation, in that sense the proposal of preestablished criteria provides a reduction of the injustices inherent of the evaluator subjectivity, as highlighted by Silva. ${ }^{26}$ This is a practice that should be disseminated as it adds quality to the teaching and learning process.

The curriculum integration model at the Tiradentes University favours the effective interdisciplinarity with the consequent development of complex thinking and of competences by students. According Suñé, Araújo and Armas, ${ }^{27}$ it is not possible to forget that training students for the life implies 2012).

${ }^{26}$ Antonio Carlos Ribeiro Silva, Educação por competências (Jundiaí: Paco Editorial,

${ }^{27}$ Letícia S. Suñé, Paulo J.L. Araújo, and Roberto de Armas. Desenho de currículo para desenvolver competências: uma proposta metodológica (Aracaju: Editora Unit, 2015). 
training them to deal with problems, involving the different real dimensions. These problems are not linear or monodimensional, namely they are not simple. Often the approach of traditional teacher and learning processes offers a too simplistic example of the reality. Real situations are multidisciplinary, cross-cutting, multi-dimensional and therefore complex.

The Guiding Basis of the Action, which is one of the stages of the learning model used by the Tiradentes University, provides students a structured sequence of operations that must be performed to facilitate the development of actions through which person of learning interact with the study objects.

It is also highlighted as a positive point of the competence-based approach used by the University Tiradentes the joint planning of teachers before the beginning of each academic year. This planning allows teachers to develop integrative activities involving two or more subjects, thus promoting interdisciplinarity and the consequent competences development. Integrated planning of educational activities is considered an aspect that favours the development of competences by students, and the improvement of the learning efficiency. This is a good practice recommended to be used widely by universities that opted for competence-based education.

\section{Bibliography}

Bender, William N. Aprendizagem baseada em Projetos: educação diferenciada para o século XXI. Porto Alegre: Penso, 2014.

Beneitone, Pablo, César Esquetini, Júlia González, Maida Marty, Gabriela Siufi, and Robert Wagenaar, eds. Reflexóes e perspectivas do ensino superior na América Latina. Bilbao: Univesidad de Deusto, 2007.

Bray, Mark, Bob Adamson, and Mark Mason. Educación comparada: enfoques y métodos. Buenos Aires: Ediciones Granica S.A, 2010.

Burón, Javier. Enseñar a aprender: introducción a la metacognición. Bilbao: Ediciones Mensajero, 2012.

Díaz Pupo, Arledys. "Propuesta de bases orientadoras de la acción para estimular las habilidades conformadoras del desarrollo personal desde la asignatura 'Psicología de la personalidad' en condiciones de Colegios Universitarios Municipales." Pensando Psicología 6, no. 10 (2010): 75-96.

Galperin cited by Héctor José García Mendoza, Ana María Ortiz Colón, Juan Martínez Moreno, and Oscar Tintorer Delgado. "La Teoría de la Actividad de Formación por Etapas de las Acciones Mentales en la Resolución de Problemas." Inter Science Place 1, no. 9 (2009): 1-25. doi: 10.6020. http://www. interscienceplace.org/isp/index.php/isp/article/view/94.

Kolb, Alice Y., and David A. Kolb. The Kolb Learning Style Inventory - Version 3.1 2005 Technical Specifications. Boston and London: HayGroup, 2005. 
http://learningfromexperience.com/media/2010/08/tech_spec_lsi.pdf.

Namay Zevallos, Wilder. "La teoría de la formación por etapas de las acciones mentales de Galperin: un esbozo teórico y casos prácticos." Scridb. https://pt. scribd.com/doc/115043666/La-teoria-de-la-formacion-por-etapas-de-lasacciones-mentales-de-P-Y-Galperin-Esbozo-teorico-y-casos-practicos.

Silva, Antonio Carlos Ribeiro. Educação por competências. Jundiaí: Paco Editorial, 2012.

Suñé, Letícia S., Paulo J.L. Araújo, and Roberto de Armas. Desenho de currículo para desenvolver competências: uma proposta metodológica. Aracaju: Editora Unit, 2015.

Tobón, Sergio T. Formación basada en competencias. Bogotá: Ecoe Ediciones, 2005. Universidad de Deusto. Marco pedagógico. Bilbao: Artes Gráficas Rontegui, S.A.L., 2001.

Zabala, Antoni and Laia Arnau. Métodos para la enseñanza de las competencias. Barcelona: Editorial GRAÓ, 2014.

\section{About the Authors}

LETÍCIA SAMPAIO SUÑÉ (letisune@uol.com.br) is a post-doctorate in Competence-based Curriculum at the University of Havana (Cuba) since 2014. She is currently retired professor of the Chemical Engineering Department of Federal University of Bahia (Brazil), visiting research professor at the Tiradentes University and researcher in the area of Competence-based Curriculum. She has extensive experience in evaluation of courses and institutions in Brazil and Latin American countries and is specialising in Competence-based Education promoted by International Tuning Academy (http://tuningacademy.org/). She holds a PhD in Chemical Engineering from the State University of Campinas (1993), Master in Chemical Engineering from the Federal University of Rio de Janeiro (1978) and graduate degree in Chemistry Engineering from the Federal University of Bahia (1975).

ROBERTO DE ARMAS URQUIZA (roberto@rect.uh.cu) holds a PhD in Biological Sciences and is Emeritus Professor of the University of Havana (Cuba) with 50 years of experience in teaching, research and university management; for which he has received awards and recognitions. He chairs the Technical Committee Reviewer Careers of the National Accreditation Board of the Republic of Cuba as a member of its Executive Secretariat. He participates in thematic networks and international projects related to innovative curricula and quality in higher education and in assessment of programs and institutions. He is a visiting professor of numerous universities in Latin America and Europe, supervisor of undergraduate and graduate theses and author of books, chapters of books and numerous scientific articles. He specializes in Competence-based Education promoted by Tuning Academy. 


\title{
Compared education study: curriculum design for the development of competences (Tiradentes University - University of Deusto)
}

\author{
Letícia Soares de Vasconcelos Sampaio Suñé \\ and Roberto de Armas Urquiza
}

\section{Copyright}

Copyright for this article is retained by the Publisher. It is an Open Access material that is free for download, distribution, and or reuse in any medium only for non-commercial purposes; provided any applicable legislation is respected, the original work is properly cited, and any changes to the original are clearly indicated. 